JURNAL PENDIDIKAN AKUNTANSI DAN KEUANGAN

Vol. 7, No. 1, [Januari-Juni], 2019: 11-20

\title{
Pengaruh Pendapatan Garansi Bank Terhadap Laba Operasional
}

\author{
Sugiyanto \\ Program Studi Manajemen, Institut Manajemen Koperasi Indonesia (IKOPIN), Bandung, Indonesia
}

\begin{abstract}
This research was conducted to determine influence of the bank guarantee revenue to the operating profit at PT Bank BJB Tbk Cabang Utama Bandung Period from January to December 2015. This research used a quantitative method. Data collection techniques used observation and literature study. The writer used Pearson correlations analysis, determination and Regression. The result showed that the correlation between revenue of bank guarantee and operating profit at PT. Bank BJB Tbk Cabang Utama Bandung Period from January to December 2015 had a vey low relationship with level of correlation coefficient as much as 0,189. While the influence of guarantee bank to operating profit was found to be 0,36\% and the remaining of 99,64\% was influenced by other factors which were not observed by the writer. There were obstacles in this research, such as; incompleteness of supporting document, there was collectability of customers at the time of analysis BI-Checking, as well as the legality of the company that were not updated or a change of leadership. The suggestion for the company is to improve the publishing process faster, in order to increase customer's confidence so that an application for a bank guarantee will be more and income on bank guarantee will be even greater.
\end{abstract}

Keywords. bank guarante revenue; operating profit.

\begin{abstract}
Abstrak
Penelitian ini dilakukan untuk mengetahui pengaruh pendapatan garansi bank terhadap laba operasional pada PT Bank BJB Tbk Cabang Utama Bandung Periode Januari - Desember 2015. Penelitian ini menggunakan metode penelitian kuantitatif, teknik pengumpulan data melalui wawancara, observasi, dan studi kepustakaan. Peneliti menggunakan analisis Pearson, determinasi, dan Regresi Sederhana. Hasil penelitian menunjukkan bahwa keterkaitan pendapatan garansi bank dan laba operasional pada PT Bank BJB Tbk Cabang Utama Bandung mempunyai tingkat hubungan sangat rendah dengan nilai koefisien korelasi sebesar 0,189. Sedangkan besar pengaruh pendapatan garansi bank terhadap laba operasional ditemukan sebesar 0,36\% dan sisanya sebesar 99,64\% dipengaruhi faktor lainnya yang tidak diteliti oleh penulis. Adapun kendala dalam penelitian ini yaitu ketidaklengkapan dokumen pendukung, terdapat kolektabilitas nasabah pada saat analisis BI - Checking serta legalitas perusahaan yang sudah tidak update atau ada perubahan kepemimpinan. Adapun saran untuk perusahaan yaitu sebaiknya meningkatkan proses penerbitan lebih cepat, agar kepercayaan nasabah meningkat sehingga permintaan untuk penetbitan garansi bank lebih banyak dan pendapatan atas penerbitan garansi bank akan semakin besar.
\end{abstract}

Kata Kunci. laba operasional; pendapatan garansi bank.

Corresponding author. Email. Sugianto_ikhsan@yahoo.co.id

How to cite this article. Sugiyanto, S. (2019). Pengaruh Pendapatan Garansi Bank Terhadap Laba Operasional. Jurnal Pendidikan Akuntansi Dan Keuangan, 7(1), 11-20. Retrieved from http://ejournal.upi.edu/index.php/JPAK/article/view/15800

History of article. Agustus 2018, Revision: November 2018, Published: Januari 2019

\section{PENDAHULUAN}

Bank menurut Undang-Undang Nomor

10 Tahun 1998 tentang Perbankan adalah badan usaha yang menghimpun dana dari masyarakat dalam bentuk simpanan dan menyalurkannya ke masyarakat dalam bentuk kredit dan atau bentuk-bentuk lainnya dalam rangka meningkatkan taraf hidup rakyat banyak. Dilihat dari pengertian diatas bank memiliki fungsi utama meliputi penghimpunan dana dan pembiayaan, selain itu bank juga memiliki fungsi tambahan salah satunya yaitu memberikan garansi bank. Garansi bank merupakan jaminan pembayaran yang 
diberikan oleh bank kepada suatu pihak, baik perorangan, perusahaan atau badan/lembaga lainnya dalam bentuk jaminan. Pemberian jaminan dengan maksud bank menjamin akan memenuhi (membayar) kewajiban-kewajiban dari pihak yang dijaminkan kepada pihak yang menerima jaminan, apabila yang dijamin di kemudian hari ternyata tidak memenuhi kewajiban kepada pihak lain sesuai dengan yang diperjanjikan atau cidera janji. Garansi bank diterbitkan atas dasar permintaan dari nasabahnya. Dalam memberikan setiap bantuan fasilitas pada umumnya tujuan utama bank yaitu memperoleh laba yang optimal. Laba merupakan faktor penunjang kelangsungan hidup bank, dimana setiap aktivitas bank yang berupa transaksi dalam rangka menghasilkan laba dicatat, diklasifikasikan dan disajikan dalam lapora keuangan yang digunakan untuk mengukur hasil operasinal bank pada suatu periode tertentu. Guna kepentingan bisnis dalam setiap penerbitan garansi bank, selain akan meningkatkan kredibilitas bank di mata para nasabahnya, bank pun akan memperoleh keuntungan dari biaya-biaya yang harus dibayar nasabah yang dimana biaya-biaya tersebut dapat dikatakan laba oleh bank, oleh karena itu semakin banyaknya jumlah penerbitan garansi bank maka biaya-biaya yang diterima bank akan tinggi pula sehingga pendapatan dari penerbitan garansi bank akan besar. Akan tetapi untuk kepentingan bisnis dan target pencapaian fee based income dari transaksi garansi bank, bank berhak menetapkan biaya lebih tinggi dari yang dipersyaratkan dengan tetap memperhatikan faktor pelayanan, persaingan dengan bank lainnya serta kesepakatan dengan nasabah.

Tujuan Penelitian ini yaitu (1) Untuk mengetahui perkembangan pendapatan garansi bank pada PT Bank BJB Tbk Cabang Utama Bandung periode Januari-Desember 2015 (2) Untuk mengetahui perkembangan laba operasional pada PT Bank BJB Tbk Cabang Utama Bandung periode Januari-Desember
2015. (3) Untuk mengetahui besarnya pengaruh pendapatan garansi bank terhadap laba operasional pada PT Bank BJB Tbk Cabang Utama Bandung periode JanuariDesember 2015. (3) Untuk mengetahui kendala apa saja yang dihadapi oleh PT Bank BJB Tbk Cabang Utama Bandung dalam penerbitan garansi bank (4) Untuk mengetahui upaya apa saja yang dilakukan oleh PT Bank BJB Tbk Cabang Utama Bandung untuk mengatasi permasalahan tersebut.

\section{KAJIAN PUSTAKA Konsep Bank}

Bank adalah badan usaha yang menghimpun dana dari masyarakat dalam bentuk simpanan dan menyalurkannya ke masyarakat dalam bentuk kredit dan/atau bentuk-bentuk lainnya dalam rangka meningkatkan taraf hidup rakyat banyak. Berikut merupakan definisi bank menurut para ahli (1) Menurut Kasmir (2014:5) menyatakan bahwa bank merupakan lembaga perantara keuangan antara masyarakat yang kelebihan dana dengan masyarakat yang kekurangan dana. (2) Menurut Irham Fahmi (2014:2) dalam bukunya menyebutkan bahwa kamus istilah hukum fockema Andreae mengatakan bahwa bank adalah suatu lembaga atau orang pribadi yang menjalankan perusahaan dalam menerima dan memberikan uang dari dan kepada pihak ketiga.

\section{Jenis-jenis Bank}

Dalam bukunya yang berjudul Dasardasar Perbankan Dr. Kasmir menyebutkan bahwa adapun jenis perbankan dewasa ini antara lain (1) Bank berdasarkan fungsinya yaitu: Bank Umum dan Bank Perkreditan Rakyat (BPR). (2) Bank berdasarkan kepemilikannya yaitu: Bank Pemerintah, Bank Swasta Nasional, Bank Koperasi, Bank Campuran, dan Bank Asing. (3) Bank 
berdasarkan Statusnya yaitu: Bank Devisa dan Bank Non Devisa. (4) Bank berdasarkan cara menentukan harga yaitu: Bank Konvensional dan Bank Syariah.

\section{Pendapatan}

Pendapatan berasal dari kata dasar “dapat”. Menurut Kamus Besar Bahasa Indonesia, pengertian pendapatan adalah hasil kerja (usaha dan sebagainya). Menurut Standar Akuntansi Keuangan (Ikatan Akuntan Indonesia (IAI), 2007, No.23, pendapatan didefinisikan sebagai arus masuk bruto dari manfaat ekonomi yang timbul dari aktivitas normal perusahaan selama satu periode bila arus masuk itu mengakibatkan kenaikan ekuitas yang tidak berasal dari kontribusi penanaman modal.

\section{Garansi Bank}

Istilah garansi berasal dari bahasa Inggris guarantee atau guaranty yang berarti menjamin atau jaminan. Adapun menurut Kamus Besar Bahasa Indonesia bahwa jaminan adalah janji seseorang untuk menanggung utang atau kewajiban pihak lain, apabila utang atau kewajiban tersebut tidak dipenuhi.

Garansi Bank adalah jaminan yang diterbitkan oleh bank yang mengakibatkan kewajiban membayar kepada penerima jaminan apabila terjamin cidera janji. Sumber: Pedoman Produk BJB Garansi Bank Tahun 2013.

\section{Pihak -pihak yang Terlibat}

Menurut Dr. Kasmir (2014:222) mengemukakan bahwa Penerbitan bank garansi oleh bank melibatkan berbagai pihak yang berkepentingan. Masing masing pihak memiliki tujuan dan maksud tertentu dengan penerbitan bank garansi.

Berikut pihak-pihak yang terlibat dalam garansi bank (1) Pihak Penjamin
(Bank). Bank merupakan pihak yang mengeluarkan bank garansi yang diinginkan oleh nasabah, artinya bank akan memberikan jaminan pembayaran kepada pihak lain (Pihak Ketiga) apabila nasabah yang dijaminkannya ingkar janji. (2) Pihak Terjamin (Nasabah) Nasabah dianggap memiliki uang sejumlah tertentu, sehingga oleh pihak pemberi pekerjaan (Pihak Ketiga) nasabah dianggap memiliki uang. (3) Pihak Penerima Jaminan atau Bouwheer (Pihak Ketiga). Proyek yang dikerjakan selesai tepat waktu dan sesuai pula dengan persyratan yang telah disepakati.

\section{Laba}

Laba atau keuntungan adalah salah satu tujuan utama perusahaan dalam menjalankan aktivitasnya. Pihak manajemen selalu merencanakan besar perolehan laba setiap periode, yang ditentukan melalui target yang harus dicapai. Penentuan target besarnya laba ini sangat penting guna mencapai tujuan perusahaan secara keseluruhan.

Berikut merupakan definisi laba menurut para ahli (1) Menurut Naripan (2007: 788) "Laba adalah perbedaan antara pendapatan dengan keseimbangan biaya-biaya dan pengeluaran untuk periode tertentu". (2) Menurut Islahulzzaman (2012:238) "Laba (income) adalah selisih total pendapatan (revenue) dikurangi biaya-biaya (expense) dari kegiatan usaha perusahaan yang diperoleh selama periode tertentu”.

\section{Jenis-jenis Laba}

Laba yang dicapai suatu perusahaan pada laporan laba rugi berbeda-beda tergantung pada perhitungan yang dibuat oleh bagian keuangan dengan berdasarkan pada aturan pembuatan laporan laba rugi yang telah ditetapkan yang terdiri dari laba kotor, laba operasional, laba bersih dan lain-lain. 
Berikut pembuatan laporan laba rugi (1) Laba Kotor. Laba kotor adalah perbedaan antara pendapatan dengan biaya untuk membuat suatu produk atau penyediaan jasa sebelum dikurangi biaya overhead, gaji, pajak dan pembayaran bunga. (Wikipedia) (2) Laba Operasional. Menurut Amir Abdi Yusuf (2000:84), "Laba operasional adalah selisih lebih pendapatan yang merupakan hasil langsung dari kegiatan perusahaan dikurangi dengan kegiatan operasional suatu usaha". (3) Laba Bersih. Laba bersih (net income) adalah laba yang diperoleh dalam tahun buku berjalan setelah dikurangi taksiran utang pajak. Laba bersih atau "Garis Bawah" adalah laba perusahaan sesudah memperhitungkan semua pendapatan dan beban yang dilaporkan semasa periode akuntansi.

\section{METODE PENELITIAN}

Pada saat akan melakukan sebuah penelitian, seorang peneliti sebaiknya menentukan terleb ih dahulu metode penelitian yang akan digunakan, sehingga akan mempermudah langkah-langkah penelitian. Menurut Sugiyono (2011:2), "Metodelogi penelitian adalah cara ilmiah untuk mendapatkan data dengan tujuan dan kegunaan tertentu."

Berdasarkan variabel penelitian, metode yang akan digunakan penulis dalam penelitian ini adalah metode kuantitatif dengan pendekatan deskriptif. Menurut Elvinaro Ardianto (2010:47), "Metode penelitian kuantitatif adalah penelitian yang sarat dengan nuansa angka-angka dalam teknik pengumpulan data yang perhitungannya menggunakan metode statistik."

Dan menurut Sugiyanto (2011:147), "Statistik deskriptif digunakan untuk menganalisis data dengan cara mendeskripsikan atau menggambarkan data yang telah terkumpul sebagaimana adanya tanpa bermaksud membuat kesimpulan yang berlaku untuk umum dan generalisasi."

Dalam hal pengukuran variabel penulis menggunakan 2 (dua) variabel, yaitu (1) Variabel Independen (Variabel Bebas). Variabel Independen adalah variabel yang mempengaruhi atau yang menjadi sebab timbulnya variabel dependen (terikat). Variabel independen yang diteliti dalam penelitian ini adalah pendapatan garansi bank (X). (2) Variabel Dependen (Variabel Terikat) Variabel dependen adalah variabel yang dipengaruhi atau yang menjadi akibat, karena adanya variabel bebas. Variabel dependen dalam penelitian ini adalah laba operasional (Y).

\section{Populasi dan Sampel}

Menurut Sugiyono (2010:80), "populasi adalah wilayah generalisasi yang terdiri atas subjek atau objek yang mempunyai kualitas dan karakteristik tertentu yang ditetapkan oleh peneliti untuk dipelajari dan kemudian ditarik kesimpulannya."

Berdasarkan definisi populasi tersebut, dalam penelitian ini adalah data garansi bank dan laporan laba / rugi yang ada di PT. Bank BJB Tbk Cabang Utama Bandung.

Menurut Sugiyono (2010:81) "Sampel adalah bagian dari jumlah dan karakteristik yang dimiliki oleh populasi tersebut." Sampel yang dipilih oleh peneliti harus betul-betul mewakili.

Dalam penyusunan penelitian ini, sample yang diteliti adalah data pendapatan garansi bank dan laba operasional yang ada di laporan laba / rugi PT Bank BJB Tbk Cabang Utama Bandung untuk periode JanuariDesember 2015.

\section{Teknik Pengumpulan Data}


Salah satu kegiatan dalam penelitian adalah mengumpulkan data-data yang tepat. Data-data dalam penelitian dapat dikelompokan menjadi dua bagian yaitu data primer dan data sekunder. Berikut adalah cara penelitian dalam mengumpulkan data (1) Data Primer. Sumber data yang langsung memberikan data kepada pengumpul data dengan melakukan penelitian langsung ke lapangan, dengan meliputi mengamati aktivitas terhadap objek yang diteliti untuk mendapatkan informasi-informasi dan data yang dibutuhkan untuk melanjutkan suatu penelitian. Wawancara dengan cara berkomunikasi dengan mengajukan beberapa pertanyaan yang bertujuan untuk memperoleh data informasi. (2) Data Sekunder, Sumber data yang tidak langsung memberikan data kepada pengumpul data. Data sekunder merupakan data yang digunakan untuk mendukung informasi dari data primer. Studi Kepustakaan dengan cara mencari sumber referensi informasi untuk mengembangkan hasil penelitian.

\section{HASIL DAN PEMBAHASAN}

Perkembangan Pendapatan Garansi Bank Pada PT Bank BJB Tbk Cabang Utama Bandung periode Januari - Desember 2015

Dalam penelitian ini variabel bebas yang diteliti adalah pendapatan garansi bank. Berikut perkembangan jumlah pendapatan garansi bank pada PT Bank BJB Tbk Cabang Utama Bandung periode Januari - Desember 2015.

Tabel 1. Perkembangan Pendapatan Garansi Bank pada PT Bank BJB Tbk Cabang Utama Bandung periode Januari - Desember 2015

\begin{tabular}{|c|c|c|c|c|c|c|}
\hline \multirow[b]{2}{*}{ Bulan } & \multicolumn{5}{|c|}{ Garansi Bank } & \multirow[b]{2}{*}{ Total } \\
\hline & $\begin{array}{c}\text { Pena } \\
\text { wa } \\
\text { ran } \\
\text { (TD) }\end{array}$ & $\begin{array}{c}\text { Pela } \\
\text { ksan } \\
\text { aan } \\
(P L)\end{array}$ & $\begin{array}{c}\text { Peme } \\
\text { lihara } \\
\text { an } \\
(\mathrm{PM})\end{array}$ & $\begin{array}{l}\text { Uang } \\
\text { Muka } \\
\text { (UM) }\end{array}$ & $\begin{array}{c}\text { Pem } \\
\text { baya } \\
\text { ran } \\
(\mathrm{PB})\end{array}$ & \\
\hline Jan & $\begin{array}{l}2,26 \\
5,49 \\
5.00\end{array}$ & $\begin{array}{l}5,36 \\
9,00 \\
1.78\end{array}$ & $\begin{array}{l}2,068, \\
315.00\end{array}$ & 0 & 0 & $\begin{array}{c}9,702,81 \\
1.78\end{array}$ \\
\hline Feb & $\begin{array}{c}18,7 \\
87,4 \\
92.0 \\
0\end{array}$ & $\begin{array}{l}4,89 \\
0,09 \\
0.00\end{array}$ & $\begin{array}{c}300,00 \\
0.00\end{array}$ & 0 & 0 & $\begin{array}{c}23,977,5 \\
82.00\end{array}$ \\
\hline Mar & $\begin{array}{c}60,8 \\
61,9 \\
02.0 \\
0\end{array}$ & $\begin{array}{c}36,4 \\
02,4 \\
17.0 \\
0\end{array}$ & $\begin{array}{c}900,00 \\
0.00\end{array}$ & $\begin{array}{c}273,68 \\
6,850 . \\
00\end{array}$ & 0 & $\begin{array}{c}371,851 \\
169.00\end{array}$ \\
\hline Apr & $\begin{array}{c}46,9 \\
79,0 \\
63.0 \\
0\end{array}$ & $\begin{array}{c}56,5 \\
98,0 \\
04.0 \\
0\end{array}$ & $\begin{array}{l}4,497 \\
800.00\end{array}$ & $\begin{array}{c}373,60 \\
0,000 . \\
00\end{array}$ & 0 & $\begin{array}{c}481,674 \\
867.00\end{array}$ \\
\hline Mei & $\begin{array}{c}27,8 \\
91,2 \\
51.0 \\
0\end{array}$ & $\begin{array}{c}45,5 \\
91,6 \\
01.6 \\
3\end{array}$ & $\begin{array}{l}3,189 \\
125.00\end{array}$ & 0 & 0 & $\begin{array}{c}76,671,9 \\
77.63\end{array}$ \\
\hline Jun & $\begin{array}{c}19,7 \\
32,4 \\
22.0 \\
0\end{array}$ & $\begin{array}{c}29,8 \\
32,3 \\
85.0 \\
0\end{array}$ & $\begin{array}{l}7,804, \\
331.00\end{array}$ & $\begin{array}{c}66,198 \\
, 182.0 \\
0\end{array}$ & 0 & $\begin{array}{c}123,567 \\
320.00\end{array}$ \\
\hline Jul & $\begin{array}{l}2,91 \\
0,19 \\
0.00\end{array}$ & $\begin{array}{c}155 \\
018 \\
928 . \\
50\end{array}$ & $\begin{array}{l}1,531 \\
700.00\end{array}$ & $\begin{array}{c}49,767 \\
, 361.0 \\
0\end{array}$ & 0 & $\begin{array}{c}209,228 \\
179.50\end{array}$ \\
\hline Agu & $\begin{array}{l}6,37 \\
2,84 \\
0.00\end{array}$ & $\begin{array}{c}37,5 \\
76,6 \\
08.8 \\
8\end{array}$ & $\begin{array}{l}2,198, \\
910.00\end{array}$ & $\begin{array}{c}610,30 \\
1,693 . \\
00\end{array}$ & 0 & $\begin{array}{c}656,450 \\
051.88\end{array}$ \\
\hline Sep & $\begin{array}{l}7,54 \\
8,55 \\
2.00\end{array}$ & $\begin{array}{c}40,3 \\
22,3 \\
64.1 \\
1\end{array}$ & $\begin{array}{l}6,825 \\
466.85\end{array}$ & $\begin{array}{c}52,570 \\
, 220.0 \\
0\end{array}$ & 0 & $\begin{array}{c}107,266 \\
602.96\end{array}$ \\
\hline Okt & $\begin{array}{l}6,31 \\
6,30 \\
5.00\end{array}$ & $\begin{array}{c}28,0 \\
41,7 \\
68.1 \\
3\end{array}$ & $\begin{array}{l}2,723 \\
764.00\end{array}$ & $\begin{array}{l}9,203 \\
500.00\end{array}$ & 0 & $\begin{array}{c}46,285,3 \\
37.13\end{array}$ \\
\hline Nov & $\begin{array}{c}31,4 \\
33,1 \\
51.0 \\
0\end{array}$ & $\begin{array}{c}67,8 \\
53,7 \\
89.6 \\
1\end{array}$ & $\begin{array}{l}9,775 \\
041.00\end{array}$ & $\begin{array}{c}30,995 \\
, 609.0 \\
0\end{array}$ & - & $\begin{array}{c}140,057 \\
590.61\end{array}$ \\
\hline
\end{tabular}




\begin{tabular}{|c|c|c|c|c|c|c|}
\hline \multirow[b]{2}{*}{ Bulan } & \multicolumn{5}{|c|}{ Garansi Bank } & \multirow[b]{2}{*}{ Total } \\
\hline & $\begin{array}{l}\text { Pena } \\
\text { wa } \\
\text { ran } \\
\text { (TD) }\end{array}$ & $\begin{array}{c}\text { Pela } \\
\text { ksan } \\
\text { aan } \\
(\mathrm{PL})\end{array}$ & $\begin{array}{c}\text { Peme } \\
\text { lihara } \\
\text { an } \\
\text { (PM) }\end{array}$ & $\begin{array}{l}\text { Uang } \\
\text { Muka } \\
\text { (UM) }\end{array}$ & $\begin{array}{c}\text { Pem } \\
\text { baya } \\
\text { ran } \\
(\mathrm{PB})\end{array}$ & \\
\hline Des & $\begin{array}{l}3,16 \\
7,60 \\
0.00\end{array}$ & $\begin{array}{c}37,1 \\
51,8 \\
89.1 \\
1\end{array}$ & $\begin{array}{c}41,010 \\
, 145.0 \\
0\end{array}$ & 0 & $\begin{array}{c}325 \\
743 \\
418 \\
00\end{array}$ & $\begin{array}{c}407,073, \\
052.11\end{array}$ \\
\hline
\end{tabular}

Sumber: Bank Bjb (Diolah oleh penulis)

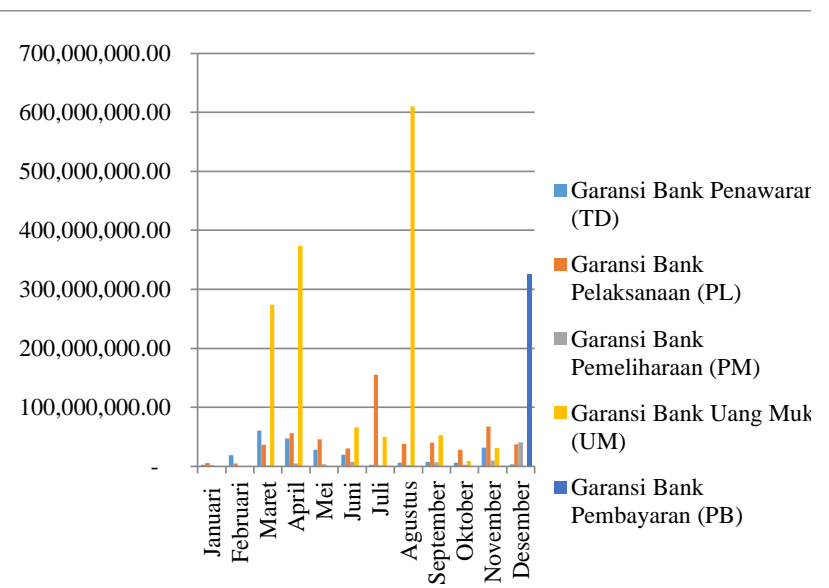

Sumber: Diolah oleh penulis

Gambar 1. Grafik Pendapatan Penerbitan Garansi Bank Pada PT Bank BJB Tbk Cabang Utama Bandung periode Januari - Desember 2015

Berdasarkan Gambar 1 di atas dapat dilihat tingkat pendapatan dari penerbitan garansi bank pada PT Bank BJB Tbk Cabang Utama Bandung periode Januari - Desember 2015 mengalami peningkatan dan penurunan. Pendapatan terbesar terjadi pada bulan agustus yaitu sebesar Rp 656.450.051,88 sedangkan pendapatan terkecil terjadi pada bulan januari yaitu sebesar Rp 9.702.811,78.

\section{Perkembangan Laba Operasional pada PT Bank BJB Tbk Cabang Utama Bandung periode Januari - Desember 2015}

Tabel 2. Laba Operasional Pada PT Bank BJB Tbk Cabang Utama Bandung periode Januaari - Desember 2015

\begin{tabular}{cr}
\hline Bulan & Laba Operasional \\
\hline Januari & $1,013,980,996.00$ \\
Februari & $2,599,571,491.00$ \\
Maret & $5,108,270,290.00$ \\
April & $6,723,468,013.00$ \\
Mei & $8,494,372,590.00$ \\
Juni & $10,302,566,402.00$ \\
Juli & $11,324,607,904.00$ \\
Agustus & $12,995,427,540.00$ \\
September & $15,190,786,318.00$ \\
Oktober & $16,753,016,774.00$ \\
November & $19,852,186,657.00$ \\
Desember & $21,789,205,708.00$ \\
\hline
\end{tabular}

Sumber: Bank BJB

Berikut grafik untuk melihat perkembangan laba operasional pada PT Bank BJB Tbk Cabang Utama Bandung periode Januari - Desember 2015.

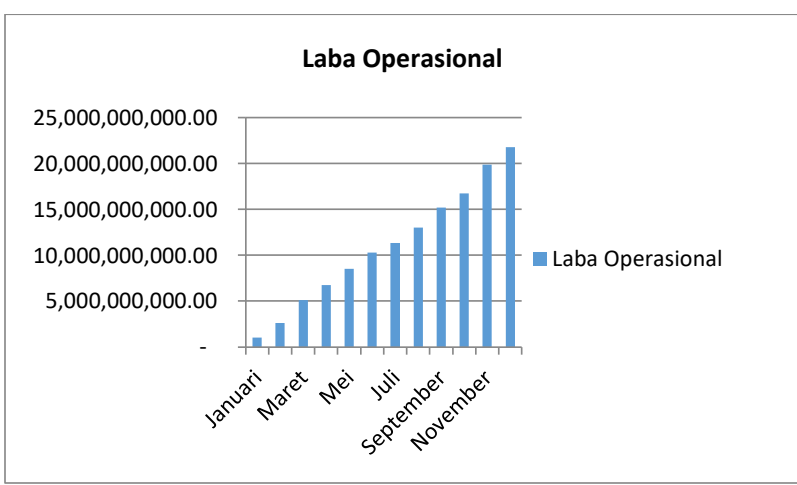

Sumber: Diolah oleh penulis

Gambar 2. Grafik Laba Operasional Pada PT Bank BJB Tbk Cabang Utama Bandung periode Januari - Desember 2015

Berdasarkan Gambar 2 di atas dapat dilihat bahwa laba operasional pada PT Bank BJB Tbk Cabang Utama Bandung periode bulan Januari - Desember 2015 mengalami peningkatan setiap bulannya, yang mana pada bulan Januari mendapatkan laba operasional sebesar Rp. 1,013,980,996.00, Februari 
sebesar Rp. 2,599,571,491.00, Maret sebesar Rp. 5,108,270,290.00, April sebesar Rp. 6,723,468,013.00, Mei sebesar Rp. $8,494,372,590.00$, Juni sebesar Rp. 10,302,566,402.00, Juli sebesar Rp. 11,324,607,904.00, Agustus sebesar Rp. 12,995,427,540.00, September sebesar Rp. 15,190,786,318.00, Oktober sebesar Rp 16,753,016,774.00, November sebesar $\mathrm{Rp}$ 19,852,186,657.00, Desember sebesar Rp. $21,789,205,708.00$.

\section{Pengaruh Pendapatan Garansi Bank Terhadap Laba Operasional Pada PT Bank BJB Tbk Cabang Utama Bandung periode Januari - Desember 2015}

Untuk mengetahui mengetahui pengaruh Pendapatan Garansi Bank (X) dan Laba Operasional (Y).

\section{Analisis Koefisien Korelasi}

Untuk mengetahui hubungan keeratan antara pendapatan garansi bank terhadap laba operasional maka dilakukan koefisien korelasi pearson, berikut adalah hasilnya :

Tabel 3. Hasil Perhitungan Koefisien Korelasi

\begin{tabular}{lrrrr} 
Model & R & R Square & $\begin{array}{c}\text { Adjusted R } \\
\text { Square }\end{array}$ & $\begin{array}{l}\text { Std. Error of } \\
\text { the Estimate }\end{array}$ \\
\hline 1 & $.189^{\mathrm{a}}$ & .036 & -.061 & $6.8002 \mathrm{E} 9$
\end{tabular}

a. Predictors: (Constant), PendapatanGB

b. Dependent Variable: LabaOps

Sumber: Data diolah Penulis dengan SPSS 17

Mengacu pada output Tabel 3 (correlations), dapat diketahui bahwa pendapatan garansi bank memiliki hubungan yang sangat rendah dengan laba operasional (nilai koefisien korelasi 0,189).

\section{Uji Analisis Determinasi}

Setelah korelasi diketahui selanjutnya adalah mencari tahu seberapa besar pengaruh Correlations

\begin{tabular}{|c|c|c|c|}
\hline & & LabaOps & $\begin{array}{c}\text { Pendapatan } \\
\text { GB }\end{array}$ \\
\hline \multirow{2}{*}{$\begin{array}{l}\text { Pearson } \\
\text { Correlation }\end{array}$} & LabaOps & 1.000 & .189 \\
\hline & PendapatanGB & .189 & 1.000 \\
\hline \multirow[t]{2}{*}{ Sig. (1-tailed) } & LabaOps & & .278 \\
\hline & PendapatanGB & .278 & . \\
\hline \multirow[t]{2}{*}{$\mathrm{N}$} & LabaOps & 12 & 12 \\
\hline & PendapatanGB & 12 & 12 \\
\hline $\begin{array}{l}\text { pendapat } \\
\text { operasion } \\
\text { koefisien }\end{array}$ & $\begin{array}{l}\text { garansi } \\
1, \quad \text { yakni } \\
\text { leterminasi, }\end{array}$ & $\begin{array}{l}\text { bank ter } \\
\text { dengan } \\
\text { erikut ada }\end{array}$ & $\begin{array}{l}\text { adap laba } \\
\text { nenghitung } \\
\text { ah hasilnya: }\end{array}$ \\
\hline
\end{tabular}

Tabel 4. Hasil Perhitungan Koefisien Determinasi
Sumber: Data diolah Penulis dengan SPSS 17

Mengacu pada output Tabel 4 (model summary), diketahui nilai $\mathrm{R}$ Square sebesar 0,189. Dengan demikian, 0,36\% laba operasional dipengaruhi oleh pendapatan garansi bank, sedangkan sisanya sebesar 99,64\% (100\%-0,36\%) dipengaruhi oleh faktor lain yang tidak diteliti oleh penulis. 


\section{Regresi Sederhana}

Analisis regresi sederhana adalah alat analisis yang digunakan untuk mengetahui besarnya pengaruh variabel independent $(\mathrm{X})$ terhadap variabel dependent (Y), yaitu pendapatan garansi bank terhadap laba operasional berikut adalah hasilnya:

Tabel 5. Hasil Perhitungan Koefisien Regresi Sederhana

\begin{tabular}{|c|c|c|c|c|c|c|}
\hline \multicolumn{7}{|c|}{ Coefficients $^{a}$} \\
\hline & & $\begin{array}{l}\text { Unstan } \\
\text { Coeff }\end{array}$ & $\begin{array}{l}\text { dardized } \\
\text { icients }\end{array}$ & $\begin{array}{l}\text { Standar } \\
\text { dized } \\
\text { Coefficie } \\
\text { nts }\end{array}$ & & \\
\hline \multicolumn{2}{|c|}{ Model } & B & Std. Error & Beta & $\mathrm{t}$ & Sig. \\
\hline \multirow[t]{2}{*}{1} & $\begin{array}{l}\text { (Const } \\
\text { ant) }\end{array}$ & 9.689E9 & 2.928E9 & & 3.309 & .008 \\
\hline & $\begin{array}{l}\text { Penda } \\
\text { patan } \\
\text { GB }\end{array}$ & 5.984 & 9.827 & .189 & .609 & .556 \\
\hline
\end{tabular}

a. Dependent Variable: LabaOps

b. Dependent Variable: LabaOps

Sumber: Data diolah Penulis dengan SPSS 17

Mengacu pada output Tabel 5 (coefficients), diperoleh persamaan regresi sederhana yaitu $\mathrm{Y}=9.689 \mathrm{E} 9+5.984 \mathrm{X}$. Jika pendapatan garansi bank $(\mathrm{X})=0$ maka $\mathrm{Y}=$ 9.689E9.

\section{Uji Normalitas}

Tabel 6. Hasil Perhitungan Uji Normalitas Data

One-Sample Kolmogorov-Smirnov Test

\begin{tabular}{lrr}
\hline & & $\begin{array}{c}\text { Unstandardized } \\
\text { Residual }\end{array}$ \\
\hline $\mathrm{N}$ & Mean & 12 \\
& & .0000005
\end{tabular}

$\begin{array}{llr}\text { Normal } & \text { Std. } & 6.48369251 \mathrm{E} 9 \\ \begin{array}{llr}\text { Parameters } \\ \text { Most, }\end{array} & \text { Deviation } & .150 \\ \text { Extreme } & \text { Absolute } & .150 \\ \text { Differences } & \text { Positive } & \text { Negative } \\ \text { Kolmogorov-Smirnov Z } & -.107 \\ \text { Asymp. Sig. (2-tailed) } & .519 \\ & .951 \\ \text { a. Test distribution is Normal. } & \\ & \\ \text { b. Calculated from data. }\end{array}$

Sumber: Data diolah Penulis dengan SPSS 17

Berdasarkan output Tabel 6di atas, diketahui bahwa nilai signifikansi sebesar 0,951 lebih besar dari 0,05 , sehingga dapat disimpulkan bahwa data yang penulis uji berdistribusi normal.

\section{Permasalahan dalam penerbitan Garansi Bank Pada PT Bank BJB Tbk Cabang Utama Bandung}

Berikut hambatan atau kendala dalam penerbitan Garansi Bank diantaranya (1) Ketidaklengkapan dokumen pendukung sehingga memperlambat penerbitan garansi bank seperti tidak adanya foto copy akta pendirian perusahaan. (2) Pada saat melakukan analisis BI Checking ditemukan adanya kolektabilitas pada nasabah. (3) Legalitas perusahaan yang sudah tidak update atau ada perubahan kepemimpinan.

Upaya penyelesaian permasalahan dalam penerbitan Garansi Bank Pada PT Bank BJB Tbk Cabang Utama Bandung

Adapun upaya penyelesaian yang dilakukan diantaranya yaitu (1) Menginformasikan kepada nasabah dapat melalui via telepon agar melengkapi dokumen serta persyaratan yang harus dipenuhi dan nasabah dapat mengirimkan AKTA nya melalui email ataupun dapat menyerahkannya secara langsung ke bank sehingga memperlancar dalam penerbitan garansi bank. (2) Pihak bank dapat menginformasikan

18 | Jurnal Pendidikan Akuntansi dan Keuangan

DOI.10.17509/jpak.v7i1.15800 | http://ejournal.upi.edu/index.php/JPAK 
kepada nasabah yang masuk dalam kolektabilitas dengan memberitahukannya melalui via telepon untuk segera menyelesaikan kolektabilitas tersebut dan apabila nasabah telah menyelesaikan kolektabilitas tersebut maka nasabah diharapkan melampirkan bukti baik berupa surat keterangan dari bank yang bersangkutan (3) Menginformasikan kepada nasabah agar dapat memperbaharui legalitas perusahaannya atau menyerahkan legalitas perusahaan yang terbaru agar menginformasikan kepada bank jika ada perubahan dalam kepemimpinan perusahaan.

\section{KESIMPULAN DAN SARAN}

Berdasarkan penelitian yang dilakukan oleh penulis mengenai pengaruh pendapatan garansi bank terhadap laba operasional Pada PT Bank BJB Tbk Cabang Utama Bandung periode Januari - Desember 2015. Adapun kesimpulannya (1) Untuk jumlah pendapatan garansi bank di PT Bank BJB Tbk Cabang Utama Bandung setiap bulannya mengalami kenaikan dan penurunan, hal itu dikarenakan oleh jumlah permintaan berdasarkan fungsi garansi bank itu sendiri beserta tergantung pada nilai garansi banknya sehingga berpengaruh terhadap pendapatan garansi bank di setiap bulannya. Dan sedangkan untuk laba operasional pada PT Bank BJB Tbk Cabang Utama Bandung periode Januari - Desember 2015 setiap bulannya mengalami kenaikan. Yang dimana laba terbesar terdapat di bulan desember yaitu sebesar Rp. 21.789.205.708.00 dan laba terkecil yaitu di bulan januari sebesar Rp. 1.013.980.996.00.

Dalam penelitian yang dilakukan oleh peneliti tentang bagaimana pengaruh pendapatan garansi bank terhadap laba operasional pada PT Bank BJB Tbk Cabang Utama Bandung Periode Januari - Desember 2015 telah dihitung menggunakan rumus Korelasi Pearson dan mendapatkan nilai sebesar 0,189 yang menyatakan tingkat hubungan Sangat Rendah antara kedua variabel. Sedangkan dari hasil perhitungan koefisien determinasi mendapatkan nilai sebesar $0.36 \%$ dimana sebesar 99,64\% (100\%-0,36\%) dipengaruhi oleh faktor lain yang tidak diteliti oleh penulis.

Kendala yang di hadapi oleh PT Bank BJB Tbk Cabang Utama Bandung dalam penerbitan garansi bank seperti ketidaklengkapan dokumen pendukung, terdapat kolektabilitas nasabah pada saat analisis BI Checking serta legalitas perusahaan yang sudah tidak update atau ada perubahan kepemimpinan.

Upaya pemecahan masalah dalam penerbitan garansi bank di PT Bank BJB Tbk Cabang Utama Bandung yaitu dapat menginformasikan kepada nasabah untuk melengkapi dokumen sehingga mempercepat dalam penerbitan, menginformasikan kepada nasabah untuk menyelesaikan kolektabilitas serta jika legalitas perusahaan sudah tidak update maka bank dapat menginformasikan kepada nasabah untuk menyerahkan legalitas perusahaan yang terbaru ataupun menginformasikan bahwa terdapat perubahan kepemimpinan.

Berdasarkan dari pembahasan yang telah dilakukan oleh penulis maka untuk masukan bagi pihak yang membaca penelitian ini penulis memberikan saran-saran sebagai masukan yang diharapkan bermanfaat bagi semua pihak, saran-saran yang ingin penulis sampaikan yaitu:

Pada saat permohonan penerbitan garansi bank banyak yang masuk, pihak bank sebaiknya sesegera mungkin mengerjakan proses penerbitan garansi bank dan kerjakan terlebih dahulu permohonan garansi bank yang dalam penerbitannya ingin selesai secepatnya sesuai permohonan pemohon, karena jika permintaan pemohonan terpenuhi maka akan lebih meningkatkan prestasi dalam hal penerbitan garansi bank dan meningkatkan kepercayaan kepada bank serta meningkatkan reputasi bank dimata pemohon, sehingga jumlah untuk permohonan penerbitan garansi 
bank akan bertambah dan biaya-biaya yang diterima bankpun semakin besar. Dan sebaiknya untuk meminimalisir keterlambatan penerbitan akibat kurangnya dokumen pendukung, adanya kolektabilitas serta legalitas yang sudah tidak update maka pihak bank harus sesegera mungkin memberitahukan kepada nasabah yang berkaitan untuk sesegera mungkin melengkapi dokumennya ataupun menyelesaikan kolektabilitasnya.

\section{DAFTAR PUSTAKA}

Amir Abdi Jusuf. (2000). Akuntansi Keuangan Lanjutan di Indonesia. Jakarta: Salemba Empat.

Fahmi, Irham. (2014). Bank dan Lembaga Keuangan Lainnya: Teori dan Aplikasi. Bandung: Alfabeta.

Islahuzzaman. (2012). Istilah-Istilah Akuntansi \& Auditing. Jakarta: PT. Bumi Aksara.

Kasmir. (2014). Dasar-Dasar Perbankan Edisi Revisi. Depok: Raja Grafindo Persada Rajawali Pers.

Kasmir. (2012). Dasar-Dasar Perbankan. Depok: Raja Grafindo Persada Rajawali Pers.

Naripan. (2007). Penganggaran Perusahaan. Jakarta: Salemba Empat.

S.R. Soemarso. (2002). Akuntansi Suatu Pengantar. Jakarta: Salemba Empat.

Sugiyono. (2009). Statistik Untuk Penelitian. Bandung: Alfabeta. 